\title{
Biological Markers Changes at the Very Early Stage of Ageing (60-65 Years). Is There a Gender-Related Effect?
}

\author{
Daniela Teixeira $^{1}$, Mayari E Ishimura ${ }^{1}$, leda M Longo-Maugeri ${ }^{1}$, Maria L Lebrão ${ }^{2}$, Yeda AO Duarte ${ }^{2}$, and Valquiria Bueno ${ }^{1 *}$ \\ ${ }^{1}$ UNIFESP Federal University of São Paulo, Department of Microbiology, Immunology, and Parasitology, Sao Paulo, Brazil \\ ${ }^{2}$ University of São Paulo USP, Faculty of Public Health, São Paulo, Brazil
}

*Corresponding author: Bueno V, Department of Microbiology, Immunology, and Parasitology, UNIFESP Federal University of São Paulo, Rua Botucatu 862, 04023-900 Sao Paulo, Brazil, Tel: 5511 55496073; Fax: 55 1155496073; Email: valquiriabueno@hotmail.com

Received date: January 07, 2015, Accepted date: April 01, 2015, Published date: April 09, 2015

Copyright: $\odot 2015$ Teixeira D, et al. This is an open-access article distributed under the terms of the Creative Commons Attribution License, which permits unrestricted use, distribution, and reproduction in any medium, provided the original author and source are credited.

\begin{abstract}
Aging has been associated with progressive molecular and structural changes causing loss of function in several organs. There is a general hypothesis that very old individuals suffer profound modifications where different domains (immune, metabolic and cognitive) loose the tight functional interconnection present in younger bodies. However, it is not clear how this interconnection is affected at the very early stage of ageing and whether gender plays a role. Therefore, our aim was to evaluate some biological markers in non-institutionalized "healthy individuals" at the very early stage of aging (60 to 65 years old, female and male). Blood was collected and serum creatinine, albumin and glucose were measured. In addition, we evaluated these individuals for lymphocytes phenotype (T CD4 ${ }^{+}, \mathrm{T} \mathrm{CD}^{+}$, $\mathrm{CD} \mathrm{9}^{+}$) by flow cytometry in peripheral mononuclear blood cells. It was observed that at the early stage of ageing male present higher creatinine and albumin serum levels compared to female. In addition, male had higher percentages of effector memory $\mathrm{CD}^{+}$and $\mathrm{CD}^{+} \mathrm{T}$ cells and lower percentages of naive $\mathrm{CD}^{+}{ }^{+} \mathrm{T}$ cells. No differences were observed for B cells. These findings suggest that metabolic functions and immune system are compromised in male individuals at the very early stage of ageing and thus gender differences should be considered for the design of new therapies to the elderly.
\end{abstract}

Keywords: Aging; Gender; Immune system; Lymphocytes

\section{Introduction}

The natural/continuous process of ageing is associated with several changes in the organism. It is difficult to precisely identify the beginning of ageing process and in developing countries individuals are designed as "elderly" after 60 years old whereas in developed countries "elderly" are individuals over 65 years old.

Healthy ageing seems to be associated with the low burden of chronic diseases and mainly with the maintenance of a functional immune system [1,2].

Several factors play a role in the ageing process and recently it has been proposed that gender affects how ageing develops since infections, chronic diseases, and death are more frequent in elderly male individuals [3-8].

Many authors have reported changes during ageing in $\mathrm{T}$ lymphocytes with decrease of naive cells along with the accumulation of highly differentiated $\mathrm{T}$ cells [9-11]. B lymphocytes in elderly individuals present reduced antibody specificity, affinity, and isotype switch [12-16]. These changes have been associated with reduced protection against new infectious agents and inefficient response to vaccines.

The decrease of naive along with the accumulation of highly differentiated $\mathrm{T}$ cells have been explained by the decrease in thymic output [9] and higher susceptibility of naive T cells to apoptosis after antigen activation [10]. CMV infection and malignancies have also been associated with the increase of effector memory T cells $[11,17,18]$.
Another important event related to changes in immune system during ageing is the declined function of hematopoietic stem cells which is characterized by impaired lymphopoiesis and enhanced myelopoiesis [19-23]. This event could favor the expansion of myeloid-derived suppressor cells (MDSCs) which have been shown to be increased in ageing individuals. MDSCs have been associated with inflammatory conditions such as infections and cancer and could contribute for the suppressive state observed in ageing individuals [24-26].

It has been reported that the age-related decrease of naive $\mathrm{T}$ cells and increase of $\mathrm{T}$ effector memory (TEM) in peripheral blood also occurs in bone marrow. These findings suggest that the increase of homeostatic cytokines (i.e. IL-15) during ageing favors the survival an expansion of memory instead of naive cells [27].

In this study we investigated whether there are changes in the immune system at the early stage of ageing (60-65 years) and how these alterations occurs in female and male individuals.

Differences in female and male during ageing process require further evaluation for the development of improved protocols in vaccination and other therapies.

\section{Materials and Methods}

After obtaining the written informed consent from the ageing healthy individuals ( 23 women and 19 men, $60-65$ years old), $3 \mathrm{~mL}$ of heparinized peripheral blood was collected as approved by the Ethics Committee of the UNIFESP Protocol number 10904/2012.

Peripheral blood mononuclear cells (PBMCs) were isolated by Ficoll-Hypaque density gradient (Amersham Biosciences, Uppsala, 
Citation: Daniela Teixeira, Mayari E Ishimura, leda M Longo-Maugeri, Maria L Lebrão, Yeda AO Duarte and Valquiria Bueno (2015) Biological Markers Changes at the Very Early Stage of Ageing (60-65 Years). Is There a Gender-Related Effect?. Aging Sci 3: 132. doi: $10.4172 / 2329-8847.1000132$

Page 2 of 5

Sweden) centrifugation. Cells were viable frozen in RPMI, fetal bovine calf serum, and dimethylsulphoxide-DMSO-(all products from Sigma, St Louis, MO, USA), and stored $\left(-80^{\circ} \mathrm{C}\right)$ until cell phenotyping by flow cytometry analysis.

\section{Cell phenotyping}

Frozen PBMCs were thaw and RPMI was added. Cells were centrifuged and the pellet was diluted, counted, and volume adjusted $\left(1 \times 10^{6} / \mathrm{mL}\right)$. Cells were surface stained with monoclonal antibodies CD3 APC, CD4 PerCP Cy5.5, CD8 APC Cy7, CD19 PE Cy7, CD27 FITC, and CD45RA PE (eBioscience, CA, USA) for $30 \mathrm{~min}$ at $4^{\circ} \mathrm{C}$, washed in staining buffer (PBS with $0.1 \%$ BSA), and centrifuged. Live cells (based on forward and side scatter) were acquired on FACS Canto II using DIVA software (Becton Dickinson, USA). Further analyses of FACS data were performed using FLOWJO 9.3 software (Tree Star, USA).

\section{Clinical parameters}

The measurement of clinical parameters (creatinine, albumin, and glucose) was performed in blood using an automatic analyzer Dimension RXL (Siemens Laboratory Diagnostics, Tarrytown, NY, USA).

\section{Statistical analysis}

Mann-Whitney test was used for statistical analysis and values of ${ }^{*} \mathrm{p}$ $\leq 0.05$ were considered significant. All statistical analyses were performed with the aid of Graph Pad PRISM software (Graphpad, La Jolla, USA).

\section{Results}

In Figure 1A it is possible to observe that at the very early period of ageing (60-65 years) male presented a higher mean serum creatinine (female $=0.82 \mathrm{mg} / \mathrm{dL}$ versus male $=1.02 \mathrm{mg} / \mathrm{dL}$ ) than female (Figure 1B). Male also presented higher mean serum albumin (female $=3.71$ $\mathrm{g} / \mathrm{dL}$ versus male $=3.99 \mathrm{~g} / \mathrm{dL}$ ) compared to female whereas mean serum glucose $($ female $=103.2 \mathrm{mg} / \mathrm{dL}$ versus male $=90.9 \mathrm{mg} / \mathrm{dL}$ ) was similar when male and female were compared (Figure 1C).

Changes in the percentage of $\mathrm{T}\left(\mathrm{CD} 4^{+}, \mathrm{CD} 8^{+}\right)$and $\mathrm{B}$ lymphocytes and in $\mathrm{CD} 4 / \mathrm{CD} 8$ ratio have been shown during the ageing process. In this study the evaluation of mean $\mathrm{CD}^{+}$(female $=47.4 \%$ versus male $=43.3 \%), \mathrm{CD}^{+}($female and male $=23.2 \%), \mathrm{CD} 19^{+}($female $=11.9 \%$ versus male $=11.2 \%$ ) and the ratio $\mathrm{CD}^{+} / \mathrm{CD}^{+}$(female $=2.28$ versus male $=2.13$ ) showed no statistical difference when female and male at the early stage of ageing (60-65 years) were compared (Figure 2).
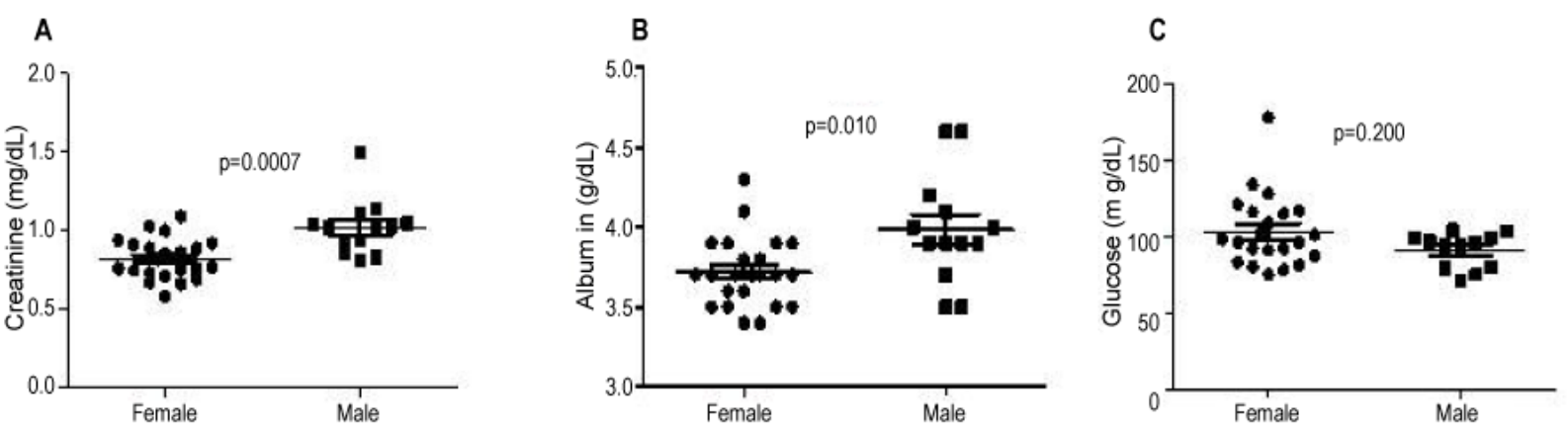

Figure 1: Blood levels of creatinine, albumin, and glucose from individuals of 60-65 years old (female versus male).

Decrease of naive cells and increase of a memory phenotype is reported in elderly individuals and it has been associated with impaired immune response to new pathogens and vaccination. Therefore, our next step was to investigate whether lymphocytes at different stages of maturation (naive, memory, and effector) show percentage changes in female and male individuals at the early stage of ageing (60-65 years). We performed the phenotype of blood circulating cells by flow cytometry using as markers CD45RA ${ }^{+}$and $\mathrm{CD} 27^{+}$. The presence of these two markers in T lymphocytes is related with naive function whereas the decrease or loss $\left(\mathrm{CD} 45 \mathrm{RA}^{\text {neg }} \mathrm{CD} 27^{+}\right.$, $\mathrm{CD}_{45 \mathrm{RA}}{ }^{+} \mathrm{CD} 27^{\text {neg }}$, and $\left.\mathrm{CD} 45 \mathrm{RA}^{\text {neg }} \mathrm{CD} 27^{\text {neg }}\right)$ is related to memory and effector functions [28].

Figure 3 shows that at the early stage of ageing (60-65 years) there was a trend towards higher mean percentage of $\mathrm{CD} 4^{+} \mathrm{T}$ lymphocyte effector memory (TEM) phenotype in male individuals (female $=13.6 \%$ versus male $=18.1 \%, \mathrm{p}=0.077$ ) whereas other phenotypes (naive, TCM, and TEMRA) presented similar mean percentages when female and male individuals were compared. $\mathrm{CD} 8^{+} \mathrm{T}$ cells showed a trend towards higher mean expression of naive (Figure 4A) phenotype in female (female $=35.5 \%$ versus male $=29.2 \%, p=0.065$ ) whereas effector memory
(TEM female $=10.4 \%$ versus male $=15.6 \%, p=0.047$ ) phenotype was significantly higher in male individuals (Figure 4C). CD8 ${ }^{+}$central memory (TCM) and effector re-expressing RA (TEMRA) T cells were expressed in similar percentages when female and male were compared (Figures $4 \mathrm{~B}$ and $4 \mathrm{D}$ respectively).

Ageing has been associated with alterations in peripheral B cell developmental system leading thus to the imbalance in naive and memory populations and decreased response to new extracellular pathogens. In B cells $\left(\mathrm{CD} 19^{+}\right)$the expression of CD27 is a marker of primed memory cells $\left(\mathrm{CD} 19^{+} \mathrm{CD} 27^{+}\right)$and its engagement promotes the differentiation of memory B cells into plasma cells. Our study showed that both naive and memory phenotype was expressed at similar mean percentages when female and male individuals at the early stage of ageing (60-65 years) were compared (Figures $5 \mathrm{~A}$ and $5 \mathrm{~B})$. We observed a mean percentage of naive $\mathrm{B}$ cells over $60 \%$ $\left(\mathrm{CD} 19^{+} \mathrm{CD} 27^{-}\right.$; female $=60.8 \%$ versus male $\left.=62.7 \%\right)$ whereas memory $\mathrm{B}$ cells were under $40 \% \quad\left(\mathrm{CD} 19^{+} \mathrm{CD} 27^{+} ; \quad\right.$ female $=37.0 \%$ versus male $=34.7 \%$ ). 
Citation: Daniela Teixeira, Mayari E Ishimura, leda M Longo-Maugeri, Maria L Lebrão, Yeda AO Duarte and Valquiria Bueno (2015) Biological Markers Changes at the Very Early Stage of Ageing (60-65 Years). Is There a Gender-Related Effect?. Aging Sci 3: 132. doi: $10.4172 / 2329-8847.1000132$

Page 3 of 5
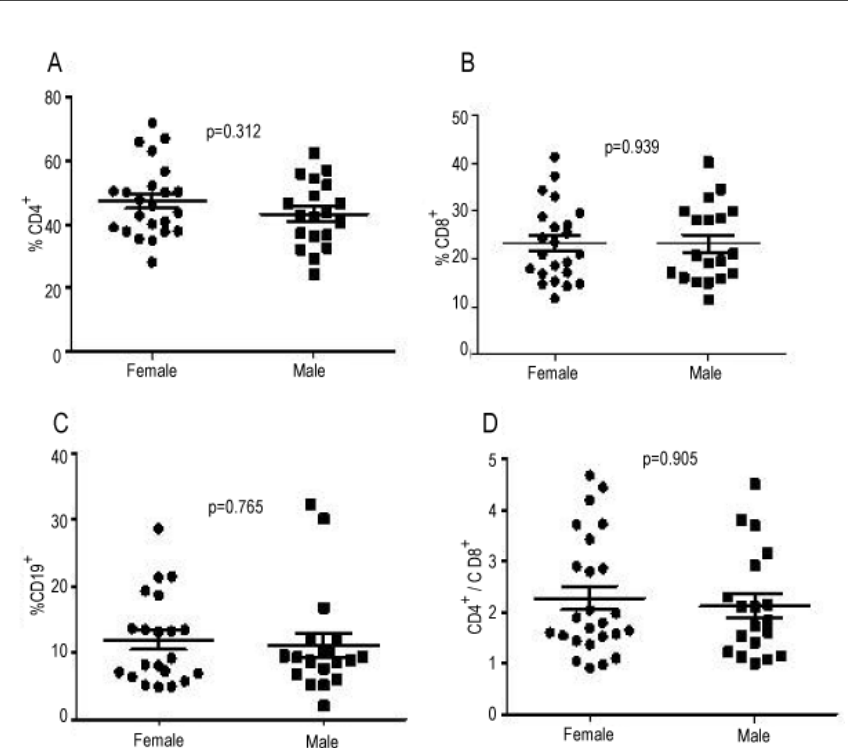

Figure 2: (A) Percentage of $\mathrm{CD}^{+}$, (B) $\mathrm{CD}^{+}$, (C) $\mathrm{CD}^{+} 9^{+}$, (D) $\mathrm{CD} 4 / \mathrm{CD} 8$ ratio in the peripheral blood from individuals of 60-65 years old (female versus male).

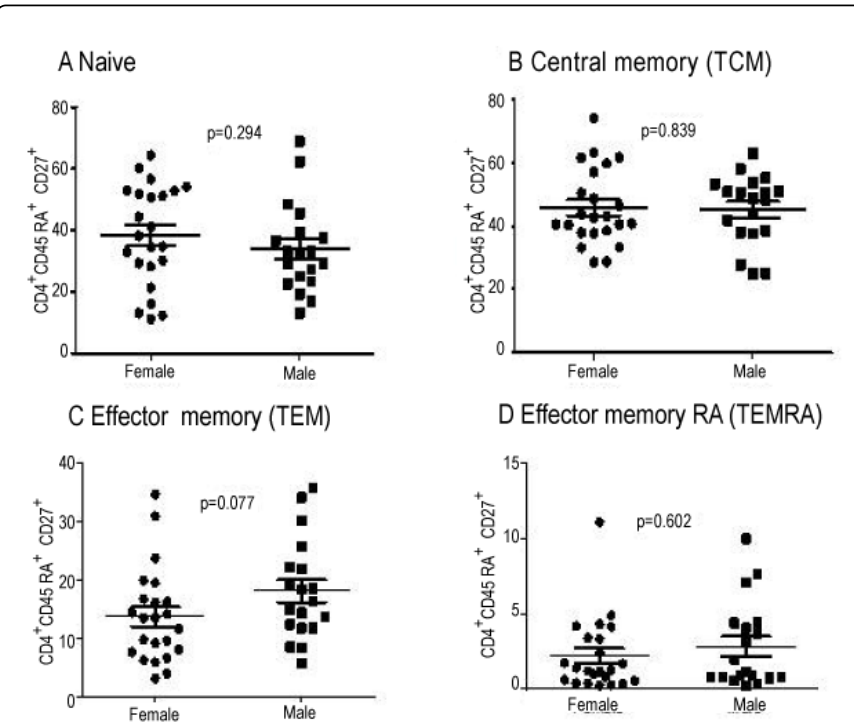

Figure 3: (A) Percentage of $\mathrm{CD} 4^{+}$naive, (B) $\mathrm{CD} 4^{+}$central memory, (C) $\mathrm{CD}^{+}$effector memory, and (D) $\mathrm{CD}^{+}$effector memory reexpressing RA cells in the peripheral blood from individuals of 60-65 years old (female versus male).

\section{Discussion}

Recent findings point to the importance of the immune system integrity for a healthy ageing. Therefore, it is crucial to understand how changes occur in the immune system during the ageing process and the associated events.

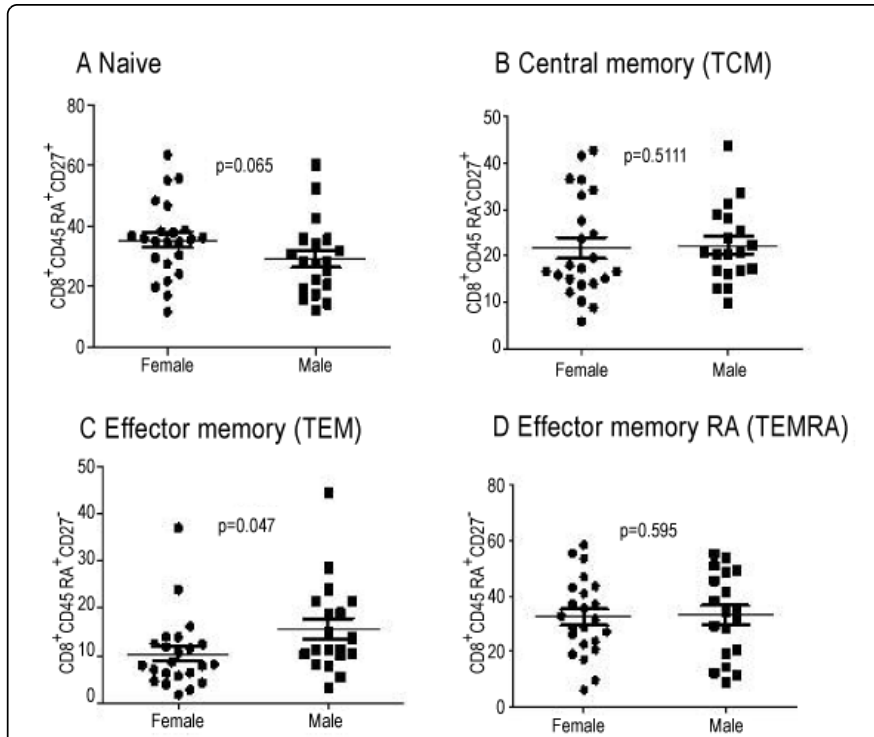

Figure 4: (A) Percentage of $\mathrm{CD} 8^{+}$naive, (B) $\mathrm{CD}^{+}$central memory, (C) $\mathrm{CD}^{+}$effector memory, and (D) $\mathrm{CD}^{+}$effector memory reexpressing RA cells in the peripheral blood from individuals of 60-65 years old (female versus male).

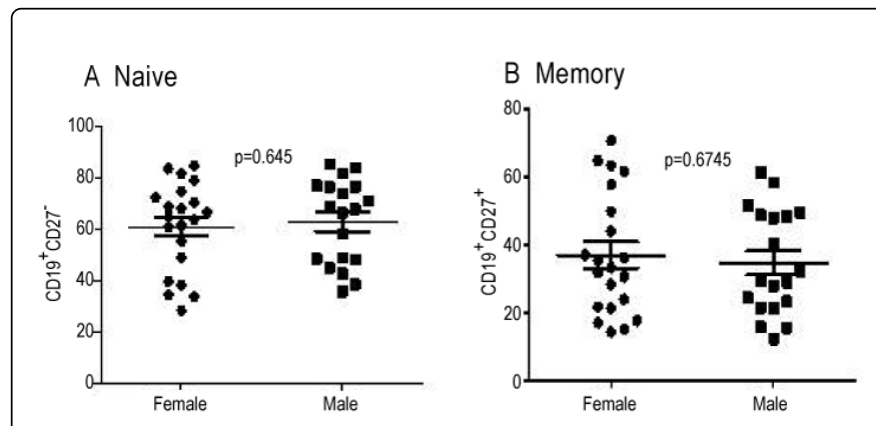

Figure 5: (A) Percentage of $\mathrm{CD}_{1} 9^{+} \mathrm{CD} 27^{-}$naive and (B) $\mathrm{CD} 19^{+} \mathrm{CD} 27^{+}$memory cells in the peripheral blood from individuals of 60-65 years old (female versus male).

Bucci et al. [29] followed centenarians for five years and found that individuals who reached longer survival presented similar serum creatinine compared to those who lived less $(1.03 \pm 0.37$ and $0.99 \pm 0.3$ $\mathrm{mg} / \mathrm{dL}$ respectively). Instead, longer survival was related to $\mathrm{CD} 4^{+}$and $\mathrm{CD}^{+}$higher percentage of naive cells, higher ratio activated/memory and effector/memory phenotype suggesting that in very old individuals the immune system is more susceptible to changes than renal function and could have a significant impact on survival. In our study, at the early stage of ageing (60-65 years), male individuals presented significantly higher mean serum creatinine (female $=0.82$ $\mathrm{mg} / \mathrm{dL}$ versus male $=1.02 \mathrm{mg} / \mathrm{dL}$ ) than female along with lower percentage of naive $\mathrm{CD}^{+} \mathrm{T}$ cells (female $=35.5 \%$ versus male $=29.2 \%$ ) and higher percentage of $\mathrm{T}$ effector memory $\mathrm{CD}^{+}$(female $=13.6 \%$ versus male $=18.1 \%)$ and $\mathrm{CD}^{+}($female $=10.4 \%$ versus male $=15.6 \%)$ suggesting more negative changes in the immune system of the male gender. 
Citation: Daniela Teixeira, Mayari E Ishimura, leda M Longo-Maugeri, Maria L Lebrão, Yeda AO Duarte and Valquiria Bueno (2015) Biological Markers Changes at the Very Early Stage of Ageing (60-65 Years). Is There a Gender-Related Effect?. Aging Sci 3: 132. doi: $10.4172 / 2329-8847.1000132$

Page 4 of 5

Weinberger et al. [30] found that CD4+ T lymphocytes are less susceptible to age-related phenotypic and functional changes than CD8+ T cells. In agreement we found for CD4+ T cells that only the effector memory (TEM) phenotype showed a trend towards higher mean percentage in male than in female individuals $(\mathrm{p}=0.077)$. For $\mathrm{CD} 8+\mathrm{T}$ cells we observed changes in two subtypes leading to a lower percentage of naive and a higher percentage of TEM in male compared to female individuals.

In healthy adult donors Hamann et al. [31] observed for $\mathrm{CD}^{+} \mathrm{T}$ cells $55 \pm 17 \%$ of naive, $25+11 \%$ of TCM, $4+3 \%$ of TEM, and $13+13 \%$ of TEMRA. Comparing with Hamann's data our results showed for both gender at the early stage of ageing (60-65 years) a lower mean percentage of naive (female $=35.5 \%$ versus male $=29.2 \%$ ) and a higher mean percentage of TEM (female $=10.4 \%$ versus male $=15.6 \%$ ) and TEMRA (female $=32.4 \%$ versus male $=33.1 \%$ ) $\mathrm{CD}^{+} \mathrm{T}$ cells. Our findings confirm that during the ageing process there is an accumulation of highly differentiated terminal cells in detriment of naive cells. In addition, we found that male individuals at the very early stage of ageing (60-65 years) were more susceptible than female to changes in $\mathrm{T}$ cell compartment.

Ageing also affects B cells (humoral response) and in addition to the decreased percentage of the naive phenotype it has been reported that elderly subjects present reduced antibody specificity, affinity and isotype switch which contribute for the impairment in the protection against infections and poor response to vaccines [32]. Bancos and Phipps [33] observed a mean percentage of $40 \%$ for naive and $60 \%$ for memory B cells in the peripheral blood of elderly subjects. In opposite, we observed a mean percentage of naive B cells over $60 \%$ (female $=60.8 \%$ versus male $=62.7 \%$ ) whereas memory B cells were under $40 \%$ (female $=37.0 \%$ versus male $=34.7 \%$ ). This difference could be due to our studied population that was at the early stage of ageing (60-65, $\mathrm{n}=23$ female and 19 male) whereas [33] evaluated individuals were older ( 60 to 72 years old; $n=6$ female and 3 male). We did not find any differences in the percentages of naive and memory B cells when female and male were compared. Other changes instead of number could occur in B cells at the early stage of ageing such as inadequate function, insufficient help from $\mathrm{T}$ cells with consequences for antibody production, specificity, affinity and isotype [34].

Several studies have shown that male suffer higher morbidity and mortality compared to female due to infections [3-7]. Also, a more efficient immune response is obtained in female after vaccinations [8]. Considering influenza vaccine one study showed that female receiving half dose developed similar antibodies in relation to male receiving full dose [35]. In agreement we found that male individuals at the very early stage (60-65 years) are more negatively affected by changes in $\mathrm{T}$ cells.

In conclusion, in our studied population the very early stage of ageing (60-65 years) was related to more prominent changes in male individuals such as higher mean creatinine levels in serum and increase of memory in detriment of naive $\mathrm{T}$ cells in peripheral blood. Gender differences should be considered for vaccination strategies and development of new therapies.

\section{References}

1. Fontana L (2009) Modulating human aging and age-associated diseases. Biochim Biophys Acta 1790: 1133-1138.
2. Vallejo AN (2007) Immune remodeling: lessons from repertoire alterations during chronological aging and in immune-mediated disease. Trends Mol Med 13: 94-102.

3. Villacres MC, Longmate J, Auge C, Diamond DJ (2004) Predominant type $1 \mathrm{CMV}$-specific memory T-helper response in humans: evidence for gender differences in cytokine secretion. Hum Immunol 65: 476-485.

4. Wagner HJ, Hornef M, Teichert HM, Kirchner H (1994) Sex difference in the serostatus of adults to the Epstein-Barr virus. Immunobiology 190: 424-429.

5. Marriott I, Huet-Hudson YM (2006) Sexual dimorphism in innate immune responses to infectious organisms. Immunol Res 34: 177-192.

6. Offner PJ, Moore EE, Biffl WL (1999) Male gender is a risk factor for major infections after surgery. Arch Surg 134: 935-938.

7. Klein SL (2004) Hormonal and immunological mechanisms mediating sex differences in parasite infection. Parasite Immunol 26: 247-264.

8. Klein SL, Jedlicka A, Pekosz A (2010) The Xs and Y of immune responses to viral vaccines. Lancet Infect Dis 10: $338-349$.

9. Fagnoni FF, Vescovini R, Passeri G, Bologna G, Pedrazzoni M, et al. (2000) Shortage of circulating naive CD8(+) T cells provides new insights on immunodeficiency in aging. Blood 95: 2860-2868.

10. Gupta S, Gollapudi S (2008) CD95-mediated apoptosis in naïve, central and effector memory subsets of CD4+ and CD8+ T cells in aged humans. Exp Gerontol 43: 266-274.

11. Derhovanessian E, Maier AB, Hähnel K, Beck R, de Craen AJ, et al. (2011) Infection with cytomegalovirus but not herpes simplex virus induces the accumulation of late-differentiated CD4+ and CD8+ T-cells in humans. J Gen Virol 92: 2746-2756.

12. Frasca D, Landin AM, Lechner SC, Ryan JG, Schwartz R, et al. (2008) Ageing down-regulates transcription factor E2A, activation-induced cytidine deaminase, and Ig class switch in human B cells. J Immunol 180:5283-5290.

13. Frasca D, Diaz A, Romero M, Landin AM, Phillips M, et al. (2010) Intrinsic defects in B cell response to seasonal influenza vaccination in elderly humans. Vaccine 28: 8077-8084.

14. Frasca D, Diaz A, Romero M, Landin AM, Blomberg BB (2011) Age effects on B cells and humoral immunity in humans. Ageing Res Rev 10: 330-335.

15. Schenkein JG, Park S, Nahm MH (2008) Pneumococcal vaccination in older adults induces antibodies with low opsonic capacity and reduced antibody potency. Vaccine 26: 5521-5526.

16. Cancro MP, Hao Y, Scholz JL, Riley RL, Frasca D, et al. (2009) B cells and aging: molecules and mechanisms. Trends Immunol 30: 313-318.

17. Busch A, Zeh D, Janzen V, Mügge LO, Wolf D, et al. (2014) Treatment with lenalidomide induces immunoactivating and counter-regulatory immunosuppressive changes in myeloma patients. Clin Exp Immunol 177: 439-453.

18. Jitschin R, Braun M, Büttner M, Dettmer-Wilde K, Bricks J, et al. (2014) CLL-cells induce IDOhi CD14+HLA-DRlo myeloid-derived suppressor cells that inhibit T-cell responses and promote TRegs. Blood 124: 750-760.

19. Warren LA, Rossi DJ (2009) Stem cells and aging in the hematopoietic system. Mech Ageing Dev 130: 46-53.

20. Morita Y, Ema H, Nakauchi H (2010) Heterogeneity and hierarchy within the most primitive hematopoietic stem cell compartment. J Exp Med 207: 1173-1182.

21. Wang J, Geiger H, Rudolph KL (2011) Immunoaging induced by hematopoietic stem cell aging. Curr Opin Immunol 23: 532-536.

22. Pang WW, Price EA, Sahoo D, Beerman I, Maloney WJ, et al. (2012) A modern understanding of the traditional and nontraditional biological functions of the angiotensin-converting enzyme. Pharmacol Rev 65: 1-46.

23. Pang WW, Price EA, Sahoo D, Beerman I, Maloney WJ, et al. (2011) Human bone marrow hematopoietic stem cells are increased in frequency and myeloid-biased with age. Proc Natl Acad Sci U S A 108: 20012-20017. 
Citation: Daniela Teixeira, Mayari E Ishimura, leda M Longo-Maugeri, Maria L Lebrão, Yeda AO Duarte and Valquiria Bueno (2015) Biological Markers Changes at the Very Early Stage of Ageing (60-65 Years). Is There a Gender-Related Effect?. Aging Sci 3: 132. doi: $10.4172 / 2329-8847.1000132$

Page 5 of 5

24. Beerman I, Bhattacharya D, Zandi S, Sigvardsson M, Weissman IL, et al. (2010) Functionally distinct hematopoietic stem cells modulate hematopoietic lineage potential during aging by a mechanism of clonal expansion. Proc Natl Acad Sci U S A 107: 5465-5470.

25. Verschoor CP, Johnstone J, Millar J, Dorrington MG, Habibagahi M, et al. (2013) Blood CD33(+)HLA-DR(-) myeloid-derived suppressor cells are increased with age and a history of cancer. J Leukoc Biol 93: 633-637.

26. Bueno V, Sant'Anna OA, Lord JM (2014) Ageing and myeloid-derived suppressor cells: possible involvement in immunosenescence and agerelated disease. Age (Dordr) 36: 9729.

27. Herndler-Brandstetter D, Landgraf K, Tzankov A, Jenewein B, Brunauer $\mathrm{R}$, et al. (2012) The impact of aging on memory $\mathrm{T}$ cell phenotype and function in the human bone marrow. J Leukoc Biol 91: 197-205.

28. Henson SM, Riddell NE, Akbar AN (2012) Properties of end-stage human $\mathrm{T}$ cells defined by CD45RA re-expression. Curr Opin Immunol 24: 476-481.

29. Bucci L, Ostan R, Giampieri E, Cevenini E, Pini E, et al. (2014) Immune parameters identify Italian centenarians with a longer five-year survival independent of their health and functional status. Exp Gerontol 54: 14-20.
30. Weinberger B, Lazuardi L, Weiskirchner I, Keller M, Neuner C, et al. (2007) Healthy aging and latent infection with CMV lead to distinct changes in CD8+ and CD4+ T-cell subsets in the elderly. Hum Immunol 68: 86-90.

31. Hamann D, Baars PA, Rep MH, Hooibrink B, Kerkhof-Garde SR, et al. (1997) Phenotypic and functional separation of memory and effector human CD8+ T cells. J Exp Med 186: 1407-1418.

32. Frasca D, Blomberg BB (2011) Aging affects human B cell responses. J Clin Immunol 31: 430-435.

33. Bancos S, Phipps RP (2010) Memory B cells from older people express normal levels of cyclooxygenase-2 and produce higher levels of IL-6 and IL-10 upon in vitro activation. Cell Immunol 266: 90-97.

34. Weksler ME (2000) Changes in the B-cell repertoire with age. Vaccine 18: 1624-1628.

35. Engler RJ, Nelson MR, Klote MM, VanRaden MJ, Huang CY, et al. (2008) Half- vs full-dose trivalent inactivated influenza vaccine (2004-2005): age, dose, and sex effects on immune responses. Arch Intern Med 168: 2405-2414. 